\begin{tabular}{|l|l|l||}
\hline \multicolumn{2}{|c|}{ PublisherInfo } \\
\hline \hline PublisherName & $:$ & BioMed Central \\
\hline \hline PublisherLocation & $:$ & London \\
\hline \hline PublisherImprintName & $:$ & BioMed Central \\
\hline \hline
\end{tabular}

\title{
Amplicon analysis
}

\begin{tabular}{|l|l|l||}
\hline \multicolumn{2}{|c|}{ ArticleInfo } \\
\hline \hline ArticleID & $:$ & 4075 \\
\hline \hline ArticleDOI & $:$ & $10.1186 /$ gb-spotlight-20010503-02 \\
\hline \hline ArticleCitationID & $:$ & spotlight-20010503-02 \\
\hline \hline ArticleSequenceNumber & $:$ & 146 \\
\hline \hline ArticleCategory & $:$ & Research news \\
\hline \hline ArticleFirstPage & $:$ & 1 \\
\hline \hline ArticleLastPage & $:$ & 2 \\
\hline \hline & & RegistrationDate : 2001-05-03 \\
ArticleHistory & $:$ & OnlineDate \\
\hline \hline ArticleCopyright & $:$ & BioMed Central Ltd2001-05-03 \\
\hline \hline ArticleGrants & $:$ & \\
\hline \hline ArticleContext & $:$ & 130592211 \\
\hline \hline
\end{tabular}




\section{Jonathan B Weitzman}

Email: jonathanweitzman@hotmail.com

The chromosomal region 17q23 is amplified in some cancer cells and is associated with poor prognosis for breast cancer. In the May 8 Proceedings of the National Academy of Sciences, Monni et al. describe the use of genomic and microarray analysis to characterize the $17 \mathrm{q} 23$ amplicon in breast cancer cells (Proc Natl Acad Sci USA 2001, 98:5711-5716). They constructed a 4 megabase contig covering the amplified region of chromosome 17, containing 17 genes and 26 expressed sequence tags (ESTs) identified from GeneMap'99. They used tissue microarray-based analysis of 184 primary breast tumor samples to define the extent of 17q23 amplification (the highest amplification frequency was $12.5 \%$ ). Subsequent microarray analysis of $636 \mathrm{cDNAs}$ from chromosome 17, including 156 transcripts within 17q23, identified five genes that are highly overexpressed in breast cancer cells. Thus, systematic amplicon analysis can identify limited numbers of genes specifically associated with cancer progression.

\section{References}

1. Detection and mapping of amplified DNA sequences in breast cancer by comparative genomic hybridization.

2. Proceedings of the National Academy of Sciences, [http://www.pnas.org]

3. A New Gene Map of the Human Genome, [http://www.ncbi.nlm.nih.gov/genemap]

4. Tissue microarrays for high-throughput molecular profiling of tumor specimens. 